\title{
20
}

\section{Modern surface pollen from the Torres Strait islands: Exploring north Australian vegetation heterogeneity}

\author{
Cassandra Rowe \\ School of Geography and Environmental Science, Monash University, Clayton, Victoria \\ cassandra.rowe@monash.edu
}

\section{Introduction}

The Cape York Peninsula region of northeastern Australia supports considerable biological diversity. It is an environment that illustrates stages in evolutionary through to historical biogeography (Mackey et al. 2001; Turner et al. 2001) and a landscape that reflects culturally based value systems, both indigenous and European (Mackey et al. 2001; McNiven et al. 2007).

Of the vegetation, Cape York Peninsula comprises a complex mosaic of plant associations and structural formations (see Neldner and Clarkson 1995). These vegetation communities reflect underlying physical environmental processes and controls (e.g. edaphic conditions), as well as the degree of climatic seasonality and consequential hydroperiod across the region (Walker and Hopkins 1990; Brock 2001). In turn, the vegetation reflects long-standing biological connections with north Australian monsoonal (wet/dry) megatherm flora, and also has links with the tropical lowland megatherm and temperate upland mesotherm flora of New Guinea (Mackey et al.2001; Turner et al.2001). In the continental context, Cape York Peninsula is distinctive in the high level of natural integrity exhibited; Cape York has relatively small, isolated human populations, minimal infrastructure development and the land-use activity is either highly localised or extensive rather than intensive (Mackey et al. 2001). The in-situ conservation of biodiversity is high, which has benefited the humid tropics - or wet tropical biome - in particular. A World Heritage listing of the wet tropics was established in the 1980s, securing $90 \%$ of Australia's surviving tropical rainforest (Abrahams et al. 1995).

Rainforest habitats occupying the humid-tropics zone have been a major focus of Quaternary research, and profiled extensively through their pollen spectra (e.g. Haberle 2005; Walker 2007). Now-refugial patches of rainforest have been shown to have great antiquity 
(Kershaw et al.2007) and changes in the pollen representation of rainforest through time have provided a guideline chronostratigraphy of other palaeoecological changes in the Cape York Peninsula (and wider) region (e.g. Kershaw 1985; see also Kershaw 1995).

The vegetative heterogeneity - the spatial and temporal connections - at Cape York Peninsula has not been well represented within palynological studies. Many of the monsoonal megatherm vegetation communities have not been captured in the same detail as rainforest, nor palynologically differentiated in terms of structure and composition. This paper seeks to capture and explore some of this missing detail. To quote Kershaw (2007:2), 'pollen analysis on the sclerophyll side of the rainforest boundary has so far proved elusive'. This 'elusiveness' hampers progress in our understanding of Quaternary vegetation-type dynamics, counteracts the up-to-date design and testing of climatic-vegetation models (Harrison et al. 2007; Lynch et al. 2007) of proxy database development/comprehensiveness (Pickett et al. 2004), limits conceptualisations of human-environment interactions and relations (Denham and Mooney 2008), and provides less long-term ecological information relevant to conservationists and land managers (Froyd and Willis 2008).

This paper presents a descriptive study of the modern pollen sampled from numerous vegetation communities within the Torres Strait, the northernmost extension of Cape York Peninsula. Sampling of modern surface (or modern analogue, Overpeck et al.1985) pollen data is a long-established technique in the interpretative refinement of fossil pollen spectra, and this study accompanies an extensive reconstruction of Quaternary Torres Strait landscapes from fossil pollen assemblages (Crouch et al. 2007; Rowe 2007a, b). The aims are (1) to characterise and differentiate monsoonal vegetation communities of the Torres Strait by their pollen, (2) to identify which pollen taxa (and in what quantities) are indicative of, or most responsible for, vegetation discrimination outside of the north Australian wet-tropical zone, and (3) to gauge the preservation of pollen taxa in the dry sedimentary context of Torres Strait.

\section{Study area}

The waters of Torres Strait extend some 45,000 km², separating Cape York Peninsula and northern Australia from New Guinea (Torres Strait Regional Authority 2007). More than 200 islands, coral and sand cays are regionally incorporated. Within this archipelago, the study-site islands of Mua and Badu form part of the southwestern geographical group, centred $70 \mathrm{~km}$ north of the Australian mainland $\left(10^{\circ} 08^{\prime} \mathrm{S}, 142^{\circ} 12^{\prime} \mathrm{E}\right.$, Figure 1$)$. Climate is strongly seasonal (tropical-isothermal classification, Stern et al.2000). Spanning $275 \mathrm{~km}^{2}$, Mua is separated from Badu by a narrow $2 \mathrm{~km}$ passage. Badu spans a smaller, $180 \mathrm{~km}^{2}$ area. Each island features a Proterozoic igneous geology, predominantly granitoids and minor interbedded volcanics, with lithosols and texture-contrast low-fertility soils. These hills rise up to $372 \mathrm{~m}$ above sea level over low-relief dune systems, plains, swamps and channels of Quaternary alluvium. Mua and Badu are fringed by degraded Quaternary coastal dunes and beaches, extending into off-shore tidal flats (Bain and Draper 1997).

Mua and Badu support 'the broadest array of plant communities and species diversity in Torres Strait' (Wannam 2008:605). Landscape disturbance through economic expansion has been minimal and isolated to the localised loss of lowland woodland and mangrove (although the islander practice of landscape firing is common). At a scale of 1:100,000, Neldner and Clarkson (1995) surveyed, mapped and described the vegetation of Cape York Peninsula, including Torres Strait (20 vegetation communities are recorded for Mua and Badu; see Table 1 and text below). Strong affinities are apparent between Torres Strait's vegetation and that of the western subregion of Cape York Peninsula, particularly in Eucalyptus and Melaleuca dominated woodlands. 


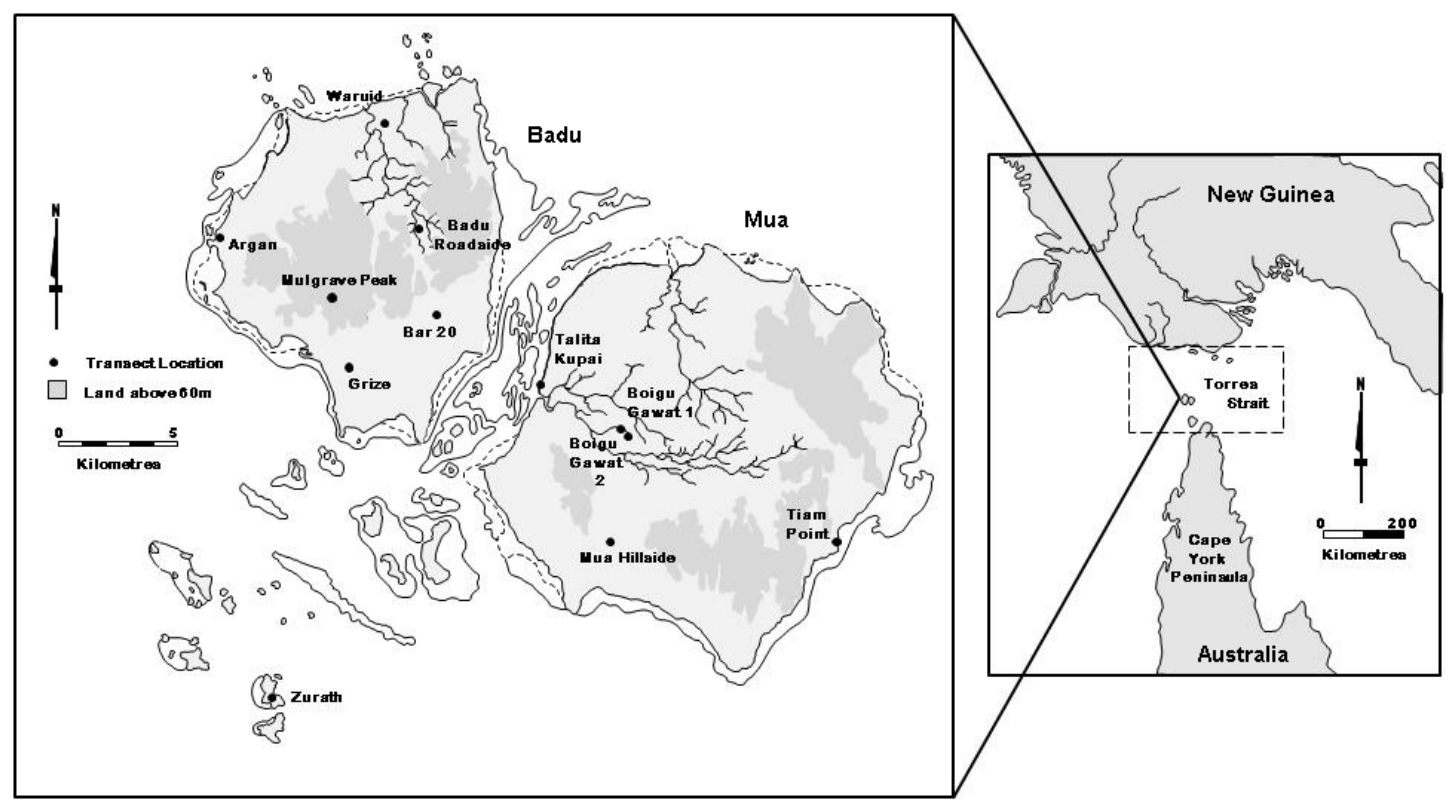

Figure 1. Location map. Position of Mua and Badu with respect to mainland Cape York Peninsula (Australia) and position of island study-site transects.

Throughout the islands'vegetation, the canopy genera Eucalytpus, Corymbia and Melaleuca are common, with the latter more widespread on the low-relief plains. Lowland woodlands incorporate a more prominent graminoid-herbaceous matrix than hill slopes, and more commonly display mixed (sub)canopy components (non-Myrtaceae, non-sclerophyll and/or malacophyll semi-deciduous taxa). Tree height and density increase with moisture availability. Monsoonal closed or vine forest occurs around watercourses or drainage lines, between bases of hills, rocky knolls and established sand ridge/swales. Mixed structured communities, incorporating Casuarina and Cocos, grow above the coastal high-water mark. Rhizophoraceaedominated mangroves occupy sheltered, shallow embayments and estuarine floodplains. Communities adjacent to mangrove stands differ according to local variation in elevation, drainage and salinity (swamp conditions, sedgeland or salt flats are observed).

\section{Methodology}

\section{Field technique}

A total of 126 modern pollen samples were collected. Of these, 50 have been used in this study. The reduced number is primarily a reflection of poor organic preservation in the thin soils or coarse sand-dominated sediments typically encountered throughout each island. Sample numbers were further reduced by subsequently merging subsamples collected within sclerophyll woodland environments. Surface samples were collected by hand and sealed in phials. Approximately $100 \mathrm{~g}$ from the uppermost $1.0 \mathrm{~cm}$ of sediment was gathered, and, where available, moss polsters were incorporated into these samples. In such cases, the whole moss polster down to, but not including, the soil was collected. At collection, the dominant canopy and understorey taxa were recorded.

Surface sediment sample collection was conducted along 12 transects designed to capture each of the major vegetation communities and plant associations, as described above (Figure 1). In turn, and for ease of presentation, the 12 transects have been grouped into four major environmental zones identified across Mua and Badu: mangrove, coastland lowland, interior swamp and sclerophyll, and rainforest (Table 2). 
Table 1. Amalgamated summary of vegetation communities located on Mua and Badu: structural and compositional characteristics (adapted from Neldner and Clarkson 1995; Fox et al. 2001; Beasley 2009).

\begin{tabular}{|c|c|c|}
\hline Vegetation community & Structure & Principal taxa \\
\hline $\begin{array}{l}\text { Corymbia and/or Eucalyptus } \\
\text { dominated woodlands, open } \\
\text { woodlands and open forests }\end{array}$ & $\begin{array}{l}\text { Tall canopy up to } 25-30 \mathrm{~m} \text {. Sparse } \\
\text { subcanopy tree layer }(15 \mathrm{~m}) \text { and } \\
\text { variable shrub layer }(4-5 \mathrm{~m}) \text {. Ground } \\
\text { layer sparse to mid-dense. }\end{array}$ & $\begin{array}{l}\text { Corymbia tessellaris, C. } \\
\text { novoguinensis, C. mesophila } \\
\text { and Eucalytpus spp. dominate. } \\
\text { Secondary tree taxa include Acacia } \\
\text { (e.g. A. flavescens), Fabaceae } \\
\text { spp., Melaleuca viridiflora, } \\
\text { Banksia dentate, Pandanus spp., } \\
\text { Lophostemon spp. and Grevillea } \\
\text { glauca occur as secondary tree/ } \\
\text { subcanopy taxa. Palms include } \\
\text { Livistonia muelleri. Utricularia, } \\
\text { Drosera, Tacca and Schoenus are } \\
\text { common ground covers. }\end{array}$ \\
\hline $\begin{array}{l}\text { Melaleuca low woodlands and } \\
\text { low-open woodlands }\end{array}$ & $\begin{array}{l}\text { Sparse upper canopy ( } 5-15 \mathrm{~m} \text { tall) } \\
\text { with scattered shrub layer and/or } \\
\text { very sparse sub-canopy tree layer } \\
\text { (<10 m). Ground cover is short and } \\
\text { sparse to moderately dense. }\end{array}$ & $\begin{array}{l}\text { Dominant Melaleuca viridiflora } \\
\text { and M. acacioides with occasional } \\
\text { emergent Corymbia and Eucalytpus } \\
\text { spp. Secondary tree taxa include } \\
\text { Banksia dentata, Asteromyrtus } \\
\text { symphocarpa, Livistonia muelleri, } \\
\text { Leucopogon and Acacia spp. } \\
\text { Heteropogen and Aristida occur } \\
\text { as ground cover; Cyperaceae (e.g } \\
\text { Fimbristylis spp.) present where } \\
\text { moist. }\end{array}$ \\
\hline $\begin{array}{l}\text { Grasslands and grassy } \\
\text { open woodlands }\end{array}$ & $\begin{array}{l}\text { Grassland to } 2 \mathrm{~m} \text {. Emergent tree } \\
\text { scattered and/or rare }(2-5 \mathrm{~m}) \text {. }\end{array}$ & $\begin{array}{l}\text { Heteropogen, Eriachne, Tacca, } \\
\text { Evolvules, Sorghum, Euphorbiaceae, } \\
\text { Fabcaeae, Convolvulaceae, Liliaceae } \\
\text { and unidentified Poaceae spp. } \\
\text { occur. Pandanus observed as single } \\
\text { emergents. Eucalytpus common on } \\
\text { sites approaching savanna. }\end{array}$ \\
\hline Rainforest & $\begin{array}{l}\text { Monsoonal closed forest to } 30 \mathrm{~m} \text {. } \\
\text { Even, evergreen canopy but sparse } \\
\text { sub-canopy and ground-layer. Vine } \\
\text { forest and/or thicket with dense, } \\
\text { uneven and semi-deciduous canopy. }\end{array}$ & $\begin{array}{l}\text { Diverse. Canopy trees } \\
\text { Welchiodendron longivalve, Acacia } \\
\text { polystachya, Terminalia muelleri, } \\
\text { Bombax ceriba, Dillenia alata, Ficus } \\
\text { and Syzgium spp. are represented. } \\
\text { Vines Flagellaria indica, Similax } \\
\text { australis, Dioscorea bulbifera, Abrus } \\
\text { precaloris, Pandorea and Alyxia spp. } \\
\text { are characteristic. }\end{array}$ \\
\hline Wetlands & $\begin{array}{l}\text { Semi-permanent swamps and } \\
\text { areas subject to inundation, high } \\
\text { water tables and/or poor drainage. } \\
\text { Structurally variable. Canopy density } \\
\text { decreases with tree height and } \\
\text { moisture availability. Shallower } \\
\text { landscape depressions and/or } \\
\text { mudflats favour herbaceous cover. }\end{array}$ & $\begin{array}{l}\text { Dominated by Melaleuca, including } \\
\text { M. quinquenervia and M. viridiflora. } \\
\text { Subdominant Pandanus spp. may be } \\
\text { present. Sparse shrub layer typically } \\
\text { composed of Melaleuca juveniles } \\
\text { and Fabaceae. Cyperaceae and } \\
\text { Restionaceae spp. well represented. } \\
\text { Aquatic groups represented by } \\
\text { Nymphaea and Nymphoides. }\end{array}$ \\
\hline Foredune and/or strand & $\begin{array}{l}\text { Discontinuous canopy; vegetation } \\
\text { often clumped and interspersed } \\
\text { with bare areas. Groundcover short, } \\
\text { dense, but also patchy. Disturbance } \\
\text { may be common. }\end{array}$ & $\begin{array}{l}\text { Casuarina equisetifolia, Scaevola } \\
\text { sericea, Cordia subcordata, } \\
\text { Guettanda and Eucalytpus spp. } \\
\text { occur as canopy components (palms } \\
\text { restricted to areas nearing human } \\
\text { habitation). Thespesia, Sporobolus } \\
\text { spp. and Ipomoea pes-caprae } \\
\text { dominate groundcover. }\end{array}$ \\
\hline
\end{tabular}


Table 2. Characteristics and environmental zone allocation of the modern surface sample transects on Mua and Badu.

\begin{tabular}{|c|c|c|c|c|c|c|}
\hline Transect name & $\begin{array}{l}\text { Central } \\
\text { coordinates }\end{array}$ & Samples & $\begin{array}{l}\text { Sample } \\
\text { interval } \\
\text { (metres) }\end{array}$ & $\begin{array}{l}\text { Transect } \\
\text { length } \\
\text { (metres) }\end{array}$ & Vegetation & $\begin{array}{l}\text { Environmental } \\
\text { zone }\end{array}$ \\
\hline Waruid & $\begin{array}{l}10^{\circ} 04^{\prime} \mathrm{N} \\
142^{\circ} 09^{\prime} \mathrm{E}\end{array}$ & $\begin{array}{l}\text { W1, W2, W3, } \\
\text { W4, W5 }\end{array}$ & 30 & 160 & $\begin{array}{l}\text { Lower-tidal mangrove; } \\
\text { upper-tidal mangrove; } \\
\text { mudflat; Corymbia and } \\
\text { Eucalyptus woodland }\end{array}$ & Mangrove \\
\hline Talita Kupai & $\begin{array}{l}10^{\circ} 10^{\prime} \mathrm{S} \\
142^{\circ} 12^{\prime} \mathrm{E}\end{array}$ & TK1, TK2, TK3 & 30 & 80 & $\begin{array}{l}\text { Upper-tidal mangrove; } \\
\text { Corymbia and Eucalyptus } \\
\text { woodland }\end{array}$ & Mangrove \\
\hline Tiam Point 1 & $\begin{array}{l}10^{\circ} 12^{\prime} \mathrm{S} \\
142^{\circ} 18^{\prime} \mathrm{E}\end{array}$ & $\begin{array}{l}\text { TP1, TP2, TP3, } \\
\text { TP4, TP5 }\end{array}$ & $20-40$ & 900 & $\begin{array}{l}\text { Coastal swamp; Melaleuca } \\
\text { and Eucalyptus open } \\
\text { woodland/savanna; } \\
\text { grassland }\end{array}$ & Coastal lowland \\
\hline Tiam Point 2 & $\begin{array}{l}10^{\circ} 12^{\prime} \mathrm{S} \\
142^{\circ} 18^{\prime} \mathrm{E}\end{array}$ & $\begin{array}{l}\text { TP1, TP6, } \\
\text { TP7,TP8 }\end{array}$ & $50-100$ & 180 & $\begin{array}{l}\text { Lower-tidal mangrove; } \\
\text { upper-tidal mangrove; } \\
\text { coastal swamp }\end{array}$ & Coastal lowland \\
\hline Argan & $\begin{array}{l}10^{\circ} 05^{\prime} \mathrm{S} \\
142^{\circ} 06^{\prime} \mathrm{E}\end{array}$ & $\begin{array}{l}\text { AG1, AG2, AG3, } \\
\text { AG4, AG5 }\end{array}$ & $50-100$ & 350 & $\begin{array}{l}\text { Upper-tidal mangrove; } \\
\text { coastal swamp, dune/ } \\
\text { strand, Corymbia and } \\
\text { Eucalyptus woodland }\end{array}$ & Coastal lowland \\
\hline Zurath & $\begin{array}{l}10^{\circ} 16^{\prime} \mathrm{S} \\
142^{\circ} 06^{\prime} \mathrm{E}\end{array}$ & $\begin{array}{l}\text { ZU1, ZU2, } \\
\text { ZU3, ZU4 }\end{array}$ & 40 & 200 & $\begin{array}{l}\text { Coastal Pandanus swamp, } \\
\text { dune/strand }\end{array}$ & Coastal lowland \\
\hline Boigu Gawat 1 & $\begin{array}{l}10^{\circ} 10^{\prime} \mathrm{S} \\
142^{\circ} 14^{\prime} \mathrm{E}\end{array}$ & $\begin{array}{l}\text { BG1-1, } \\
\text { BG1-2 }\end{array}$ & 15 & 30 & $\begin{array}{l}\text { Wetland; corymbia and } \\
\text { Eucalyptus woodland }\end{array}$ & $\begin{array}{l}\text { Inland swamp } \\
\text { and sclerophyll }\end{array}$ \\
\hline Boigu Gawat 2 & $\begin{array}{l}10^{\circ} 10^{\prime} \mathrm{S} \\
142^{\circ} 13^{\prime} \mathrm{E}\end{array}$ & $\begin{array}{l}\text { BG2-A, BG2-1, } \\
\text { BG2-2, BG2-3, } \\
\text { BG2-4 }\end{array}$ & $25-50$ & 200 & $\begin{array}{l}\text { Wetland; Corymbia and } \\
\text { Eucalyptus woodland }\end{array}$ & $\begin{array}{l}\text { Inland swamp } \\
\text { and sclerophyll }\end{array}$ \\
\hline Ваг 20 & $\begin{array}{l}10^{\circ} 08^{\prime} \mathrm{S} \\
142^{\circ} 09^{\prime} \mathrm{E}\end{array}$ & $\begin{array}{l}\text { B20-1, B20-2, } \\
\text { B20-3, B20-4 }\end{array}$ & 50 & 150 & $\begin{array}{l}\text { Wetland; corymbia and } \\
\text { Eucalyptus woodland }\end{array}$ & $\begin{array}{l}\text { Inland swamp } \\
\text { and sclerophyll }\end{array}$ \\
\hline Grize & $\begin{array}{l}10^{\circ} 09^{\prime} \mathrm{S} \\
142^{\circ} 07^{\prime} \mathrm{E}\end{array}$ & GR1 & Single & Single & $\begin{array}{l}\text { Sedgeland; corymbia and } \\
\text { Eucolyptus woodland }\end{array}$ & $\begin{array}{l}\text { Inland swamp } \\
\text { and sclerophyll }\end{array}$ \\
\hline Badu Roadside & $\begin{array}{l}10^{\circ} 06^{\prime} \mathrm{S} \\
142^{\circ} 09^{\prime} \mathrm{E}\end{array}$ & $\mathrm{BR} / \mathrm{s}$ & Single & Single & $\begin{array}{l}\text { Corymbia and Eucalyptus } \\
\text { open woodland }\end{array}$ & $\begin{array}{l}\text { Inland swamp } \\
\text { and sclerophyll }\end{array}$ \\
\hline Mua Hillside & $\begin{array}{l}10^{\circ} 12.29^{\prime} \mathrm{S} \\
142^{\circ} 14.08^{\prime} \mathrm{E}\end{array}$ & $\begin{array}{l}\text { MH1, MH2, } \\
\text { MH3, MH4, } \\
\text { MH5 MH6, } \\
\text { MH7CHECK }\end{array}$ & $50-100$ & 550 & $\begin{array}{l}\text { Semi-deciduous vine- } \\
\text { thicket, vine forest; } \\
\text { Eucalyptus and Melaleuca } \\
\text { open woodland }\end{array}$ & Rainforest \\
\hline Mulgrave Peak & $\begin{array}{l}10^{\circ} 08.15^{\prime} \mathrm{S} \\
142^{\circ} 07.87^{\prime} \mathrm{E}\end{array}$ & $\begin{array}{l}\text { MP1, MP2, } \\
\text { MP3, MP4, MP5 }\end{array}$ & $50-100$ & 850 & $\begin{array}{l}\text { Broadleaf, evergreen closed } \\
\text { forest; Eucalyptus forest and } \\
\text { (open)woodland }\end{array}$ & Rainforest \\
\hline
\end{tabular}

\section{Pollen preparation and identification}

Laboratory preparations followed standard methods of Faegri and Iversen (1989). Chemical preparations successively removed sulphur compounds, carbonates, humic acids, macrofossils, silicates and cellulose, using $\mathrm{HCL}, \mathrm{NaOH}, \mathrm{HF}$, and an acetolysis mixture consisting of $\mathrm{H}_{2} \mathrm{SO}_{4}$ 
and $\mathrm{C}_{4} \mathrm{H}_{6} \mathrm{O}_{3}$. Lycopodium markers were added to each sample to facilitate pollen concentration calculations. Pollen residues were suspended in glycerol and counted at x400 magnification under a Zeiss Axiostar compound microscope. Counting continued to a minimum of 200 grains (total pollen sum, including wetland taxa, excluding spore types).

Pollen identification was assisted by field specimen collections, authored reference material (Thanikaimoni 1987; Fuhsiung et al. 1997) and regional reference collections held at the School of Geography and Environmental Science, Monash University. A distinction in pollen of the Myrtaceae and Cyperaceae families was particularly sought after (here, limited island genera characterise different ecologies and/or where inconsistent pollen preservation may enforce a reliance on such major groups). Based on field reference collections and the discussions of Chalson (1989) and Churchill (1957, quoted in Chalson 1989), myrtaceous pollen was examined according to equatorial diameter, polar axis, polar islands, colpi depth, concavity of sides, comparative thickness of the pollen grain wall and pore characteristics. No distinction was made when fewer than half of the character-states were visible. Observations for Melaleuca include smaller size, concave sides, island presence, obviously angled colpi and thin pores. Eucalyptus is described as a larger grain, with a heavier, more robust appearance, thickened pores, convex to straight sides, and lack of polar islands. Unspecified grains fall within the category of 'Myrtaceae (undiff.)'. For Cyperaceae, only three types were considered sufficiently distinctive: Cyperus, Eleocharis and Schoenus types. In general, these pollen grains are 1-4 aperturate, elongate or more or less spheroidal, with one broad end. Eleocharis presents a more tapered shape, possibly with pores set near the base, a grain size of 30-35 $\mu \mathrm{m}$ and a surface pattern tending towards striate. Schoenus is similar, except that the exine is smoother and the grain size 32-38 $\mu \mathrm{m}$. In comparison, Cyperus is a smaller grain (to $25 \mu \mathrm{m}$ ), spheroidal and with a thicker, granular exine surface. Kershaw (1971) recognises a similar Cyperus type.

\section{Numerical analyses}

In the diagrammatic presentation of the pollen data, the Tilia suite of programs was used, specifically the spreadsheet application Tilia (2.0) and graphing counterpart TGView (v.2.0.2) (Grimm 1988). Pollen counts are expressed as a percentage of the total pollen sum. Trace pollen is considered as $<2 \%$ of the sum.

A multidimensional (or multivariate) ordination (MDS plot) was constructed for the 50-sample data set. Count values were square-root transformed and Bray-Curtis coefficients calculated (see Clarke, 1993). The Bray-Curtis index is widely used in ecology (see Faith et al. 1987), and the square-root transformation has the effect of down-weighting the importance of high-abundance taxa, so that sample similarities depend not only on these values, but on those of less common taxa. The robust nature of the ordination is measured through the numerical stress value. A stress less than two corresponds to a good ordination and useful twodimensional picture of sample similarity (Clarke 1993). An additional analysis-of-similarities (ANOSIM) function test was performed on the 50-sample data set to determine those taxa responsible for sample grouping as observed in the ordination plot, and to reveal those taxa typical of specific vegetation groups (in the sense of making large percentage contributions to the average similarity between group samples) (Clarke 1993; Clarke and Warwick 2001). In seeking out and describing vegetation pattern through pollen, these statistical techniques permit an objective test of the intuitive observations made directly from the pollen diagrams. All calculations and presentations were carried out using the PRIMER v.5 package (Plymouth Routines In Multivariate Analysis, Clarke and Gorley 2001). 


\section{Results and discussion}

Sixty-three pollen types were identified in the 50 surface sediment samples collected across Mua and Badu. Most pollen types were identified to the genus level, and unidentified taxa represent on average $10.2 \%$ of the total pollen sum. Across all samples, the average pollen concentration was 185,610 grains $/ \mathrm{cm}^{2}$.

\section{Mangrove pollen samples (Figure 2)}

Pollen assemblages from the Waruid surface samples reflect a vegetation gradient from lowtide mangrove forest, through back-mangrove mudflat to upland sclerophyll woodland, with a progressive decrease in mangrove representation and increase in non-mangrove components. At Talita Kupai, mangrove representation declines in both landward and seaward directions from the central forest sample of TK2. Eight mangrove taxa are identified in the study samples, five reaching more than trace levels.

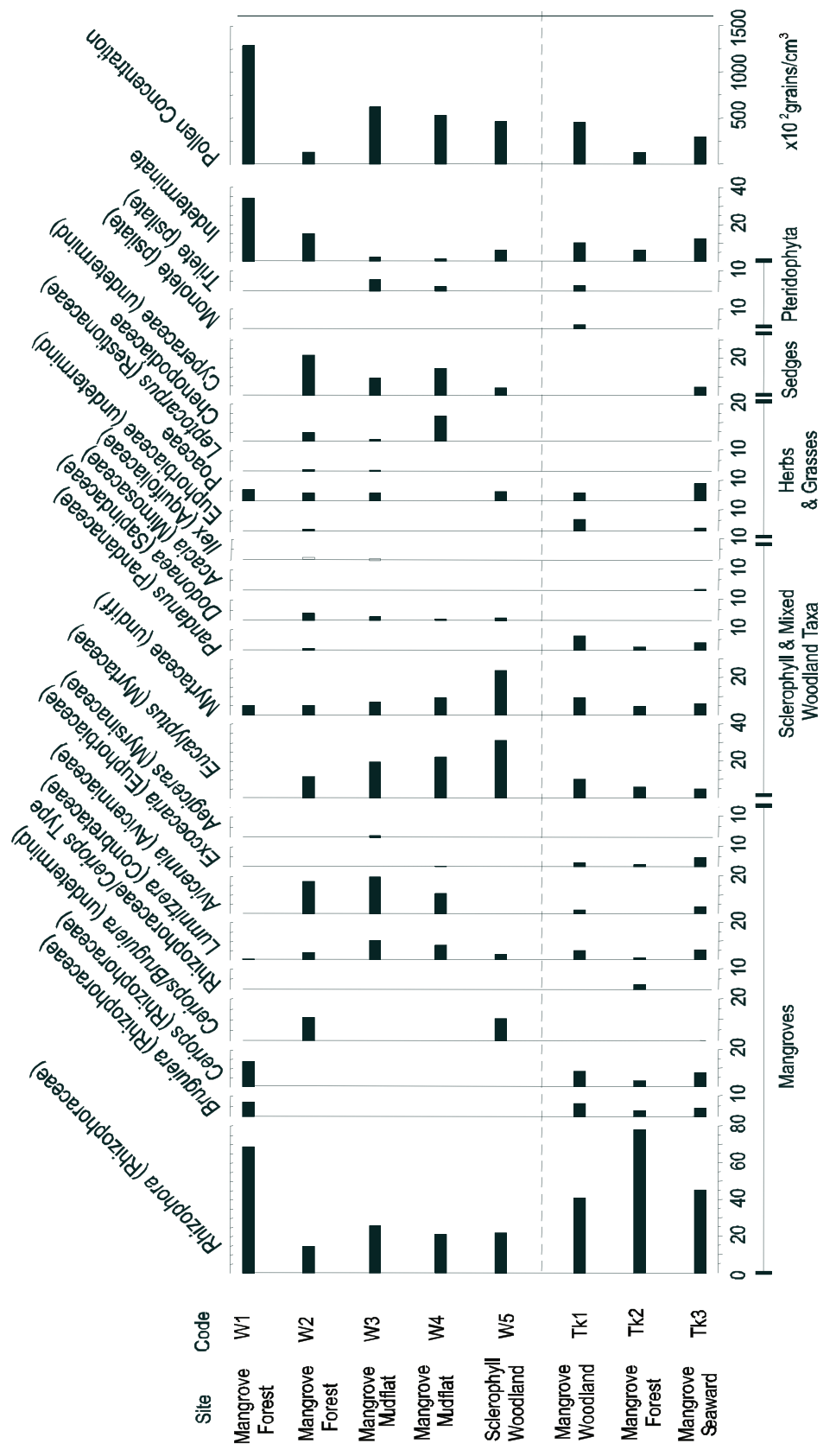

Figure 2. Mangrove pollen diagram. Modern pollen assemblages from Waruid (upper diagram) and Talita Kupai (lower diagram) transects. Pollen are expressed as percentage values of the total pollen sum. 
The family Rhizophoraceae comprises the majority of recorded mangrove taxa. Of these, Rhizophora is the most abundant. Pollen values exceed $50 \%$ in all samples from sites in which Rhizophora is found growing, declining from $70 \%$ in the seaward mangrove forest sample of W1, to $20-25 \%$ of the pollen sum in adjacent samples W2-W5. No other mangrove taxa are characteristic of this seaward forest. A more diverse mangrove pollen flora is represented in sites landward of the Rhizophora-dominated system and in close proximity to the terrestrial woodland/mangrove ecotone. Samples W2-W4 and TK1 contain a pollen assemblage in which Ceriops/Bruguiera, Lumnitzera, Excoecaria, and in particular Avicennia, are recorded alongside Rhizophora. These upper intertidal taxa comprise up to $45 \%$ of the total sum in these four samples, with an additional 15-22\% represented by Cyperaceae and Chenopodiaceae (Waruid sequence). Poaceae, Leptocarpus and Euphorbiaceae are of secondary importance across the intertidal mudflat samples of W4 and W5 $(<10 \%)$, as a factor of saline tolerances. Clear trends in mangrove to non-mangrove pollen distributions are less evident along the Talita Kupai transect. This may be partly due to the fewer samples in the sequence, but may also relate to less obvious plant species segregation on a drier site more distant from the open coast (and a strong tide).

Myrtaceae and Eucalyptus display minor pollen representation in most samples but increase gradually with distance from the central mangrove zone. Highest representation is achieved close to the parent plant source in samples W5 and TK1 (30\% and 10\% respectively). Remaining pollen types, notably Dodonaea, Ilex, Pandanus and Euphorbiaceae are recorded at low frequencies. The major terrestrial pollen types represented in samples W1 and TK3 - Eucalyptus/Myrtaceae, Pandanus and Poaceae - are known to be effectively dispersed by wind (Grindrod and Rhodes 1984) and may therefore be expected to show at least minor representation in such seaward situations and reflect regional dispersal. A discontinuous canopy at the seaward edge may also account for terrestrial pollen presence.

\section{Coastal lowland pollen samples (Figure 3)}

Pollen spectra from coastal lowland study environments fall into three groups: samples from sites within the Rhizophoraceae-dominated mangrove system, samples approaching the limit of saltwater influences, and samples extending into the surrounding upland catchment. The difference here is mangrove forest habitats defined through local mangrove representation exceeding $80 \%$ up to $100 \%$, and mangrove/terrestrial sites with longer-distance mangrove taxa contributing only $30-40 \%$ of the total pollen sum. Samples Ag3 to Ag5, Zu2 and Zu4 are noted for their absence of mangrove pollen taxa.

With the exception of Rhizophora, mangrove pollen types are poorly represented. This overriding percentage dominance of Rhizophora is directly comparable to seaward sites in the above mangrove study. Rhizophora shows strongest representation in samples fringing the seaward edge of collection (93\%) and decreases sharply landward (25\%). In general, samples TP6-TP8 and Ag1 display relatively low pollen diversity when compared with the number of pollen taxa identified in transect samples across the remainder of this study. Ceriops/Brugueria, Avicennia, Excoecaria and Xylocarpus are most common (up to 12\%) to the rear of the mangrove forest. Scyphiphora is locally abundant (16\%) adjacent to the Rhizophora-dominated forest at Argan. A diverse mangrove pollen flora associated with an increasing terrestrial presence appears an important indicator of upper-intertidal conditions and of a coastal site which has a more open canopy habit.

High pollen percentage values for Poaceae (32\%) and Cyperaceae types (10\%) occur in both coastal swamp and coastal woodland samples. Local distributions of Freycinetia and Asteraceae are reflected in surprisingly low percentage pollen values $(<5 \%)$ across swamp samples TP1-TP3. Leptocarpus has a wider, although similarly minor ( $<5 \%)$, pollen distribution through swamp- 


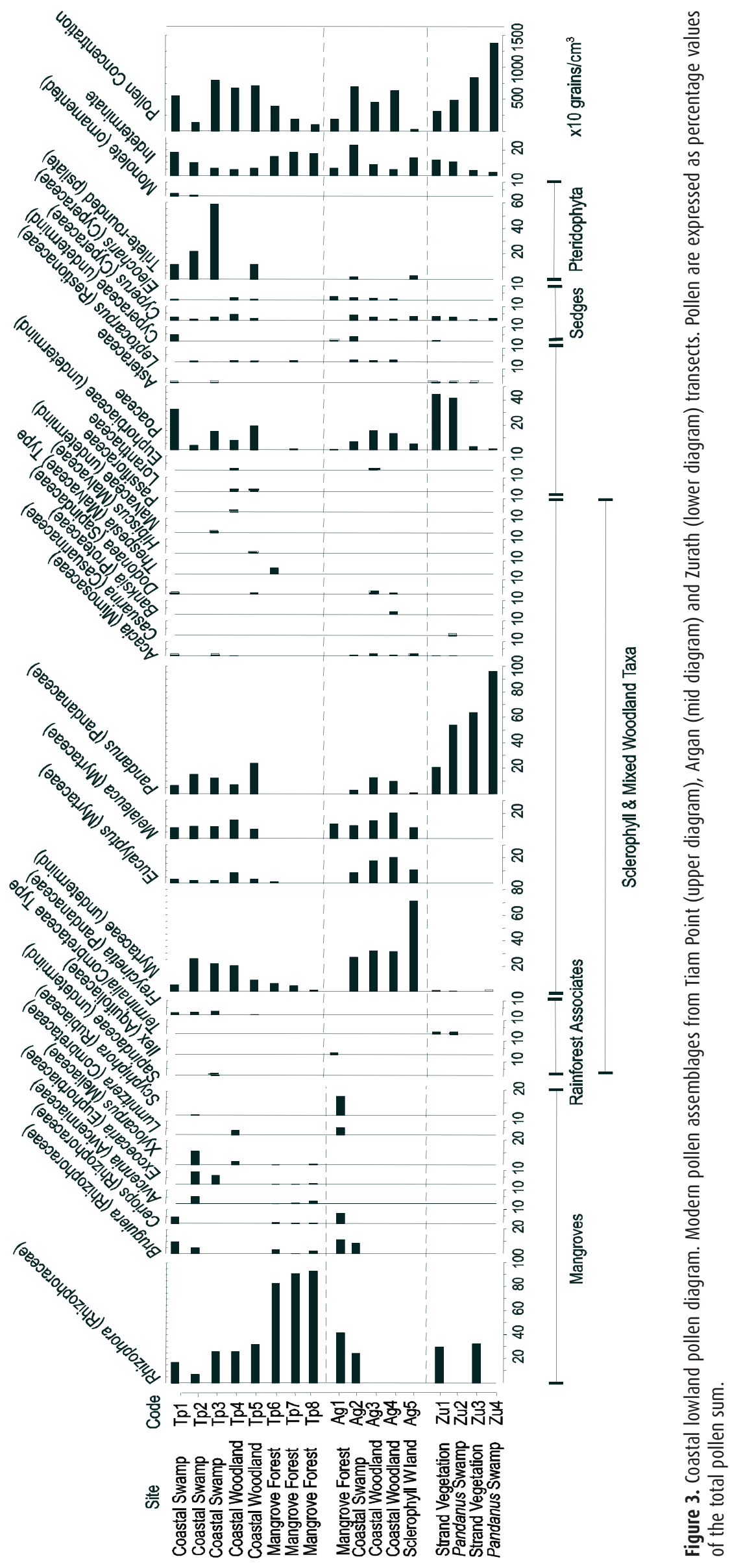


edge and woodland locations. Samples from coastal swamp habitats are also noted in particular for their abundant pteridophyta and/or spore morphologies, dominated by the rounded-trilete type (59\%) and representative of local sources. Myrtaceae dominates the coastal woodland canopy component, the highest relative pollen values for these taxa recorded with increasing distance from the seaward mangrove limit (71\% at Ag5). In general, Melaleuca pollen accounts for a greater representation than Eucalyptus, particularly surrounding the coastal swamp sites. Pandanus pollen comprises a further 7-24\% of the total assemblage, with remaining woodland types being minimally represented.

A comparison between samples $\mathrm{Zu} 1-\mathrm{Zu} 4$ and observations made on the parent vegetation of Zurath Islet indicates the absence of numerous taxa. The islet is fringed by strand vegetation dominated by dune flora. Seaward, mangroves are patchy and as such Rhizophora (ca. 30\%) is a minor component of pollen assemblages in comparison with Mua and Badu. Inland on Zurath, a narrow vine thicket becomes associated with granite outcrops but this community

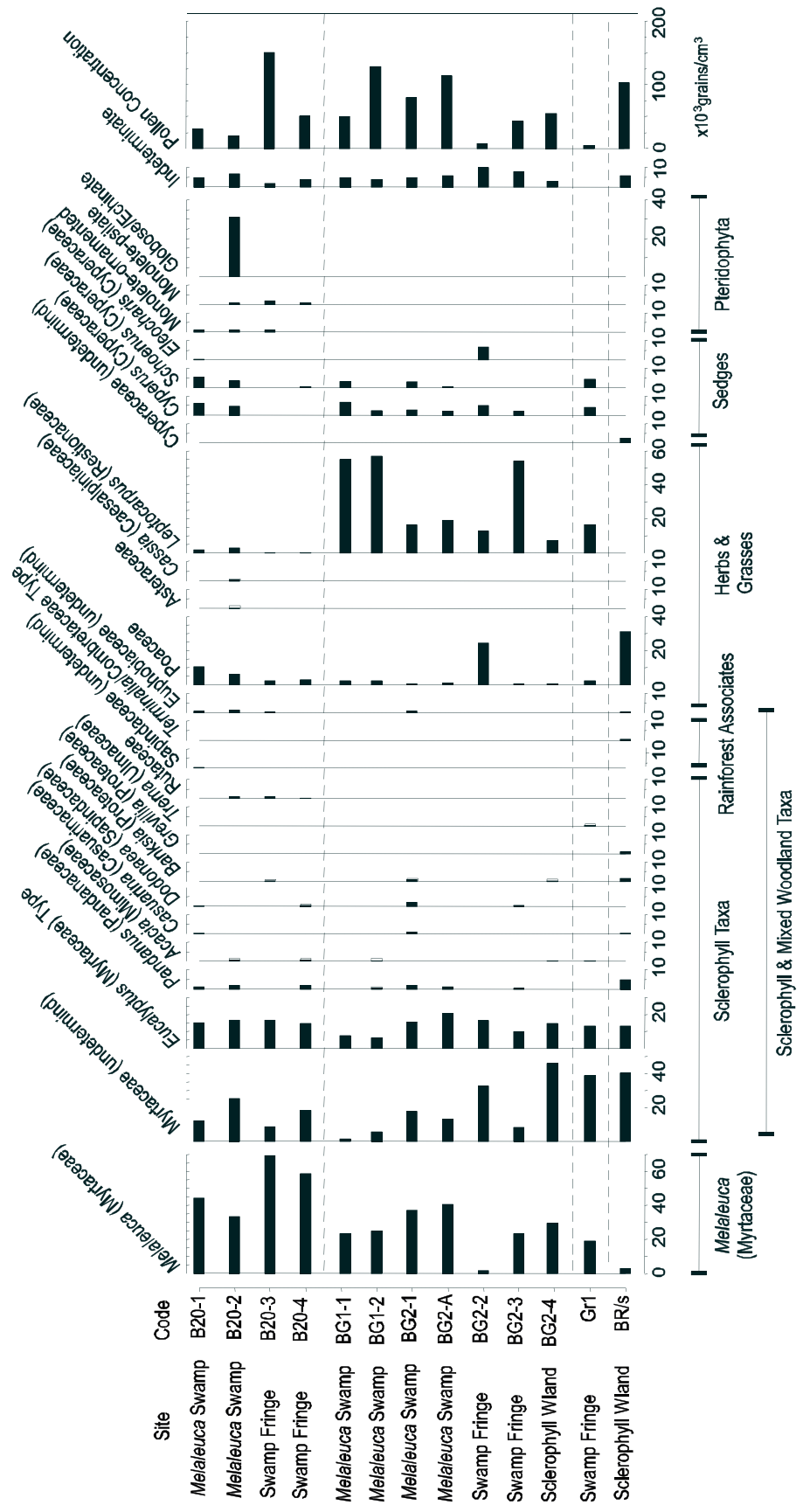

Figure 4. Inland swamp and sclerophyll pollen diagram. Modern pollen assemblages from Boigu Gawat 1 and 2 (upper diagram) Grize and Badu Roadside (lower diagram) transects. Pollen are expressed as percentage values of the total pollen sum. 
does not appear to be at all represented through pollen (see below for local deposition trends in rainforest associated pollen). High values for Poaceae pollen (40\%), recorded with herbaceous components such as Asteraceae and Cyperaceae, reflect extra-local dispersal from grassland across central islet sandy deposits. Where samples were collected from dune environments fringing Zurath Swamp, Pandanus pollen dominates the terrestrial pollen taxa at up to $96 \%$. The Zurath pollen samples also present an interesting near-absence of Myrtaceae.

\section{Inland swamp and sclerophyll pollen samples (Figure 4)}

Modern pollen content of inland swamps and sclerophyll woodlands is broadly governed by the family Myrtaceae. The dominance of Melaleuca in forming a canopy around each swamp is reflected in the high counts of both open-swamp and swamp-fringe samples; Melaleuca-type pollen generally maintains a representation of $23 \%$ to $70 \%$ and becomes increasingly important with distance from the open water. Melaleuca values exceed $60 \%$ of the pollen sum in samples B20-3 and B20-4, 25\% in BG1-2, and more than 40\% in BG2-A. The transition to open woodland can be seen in increased representation of sclerophyll canopy dominants. Myrtaceae (undiff.) achieves up to $40 \%$ of the pollen sum in samples BG2-4, GR1, and BR/s. Positioned away from swampy habitats, $\mathrm{BR} / \mathrm{s}$ is distinctive, with a combined dominance of Eucalyptus/ Myrtaceae (40\%) and Poaceae (32\%), with higher percentage values for subcanopy sclerophyll taxa such as Pandanus, Banksia and Grevillia.

Reflecting the regional importance of the surrounding woodland, Eucalyptus maintains a consistent percentage contribution of $15-21 \%$ of the total pollen sum in most samples. Myrtaceae (undiff.) shows the same trend, but with less consistency. Other taxa represented are Acacia, Casuarina, Dodonaea, Sapindaceae and Terminalia.

A reduced surface area of open water appears to have affected the proportions of locally versus regionally derived pollen components. The major difference between swamp Bar-20 samples and those from the smaller Boigu Gawat Swamp sites is the increased representation of Leptocarpus pollen to ca. $70 \%$ in the latter; Leptocarpus pollen effectively reflecting high local abundance. A similar trend is a consistent appearance of Cyperaceae pollen, incorporating Cyperus, Schoenus and Eleocharis. Pollen percentages of herbaceous taxa therefore appear more closely related to local presence or absence of parent sources at all sites, and sampling across the smaller swamp site has resulted in high percentages of the local swamp-forest understorey pollen in association with Melaleuca. Low levels of sclerophyll components in samples BG1-1 and BG1-2 are explained as dilution from local pollen. The background component of regional sclerophyll pollen is therefore generally better represented in the open-water samples where it is not filtered by dense swamp fringe vegetation (cf. Tauber 1967).

\section{Rainforest pollen samples (Figure 5)}

Rainforest taxa do not comprise the bulk of the pollen recorded in rainforest surface samples. Rainforest and allied taxa represent, as a maximum, $53 \%$ of the total pollen sum in sample MP1. At the remaining rainforest sites, this component varies from $14 \%$ to $41 \%$. In contrast, sclerophyll woodland pollen, particularly Myrtaceae and Acacia, make up at least 45\% of the pollen sum, increasing to ca. $90 \%$ outside the rainforest boundary (although it is noted that the woodland component may be inflated by pollen from local rainforest variants of Acacia and Myrtaceae, whose presence could not be differentiated from the sclerophyll category).

Along the two transects, no single rainforest pollen component predominates consistently within any sample. A large number of plant taxa are therefore under-represented within the assemblage. Rainforest samples are marked by numerous poorly represented taxa demonstrating low and often sporadic occurrence $(<5 \%)$. As best represented, values for Freycinetia range from 2-16\%, 1-11\% for Croton, and 1-10\% for Aidia. Mangifera, Alstonia, Tilliaceae and Fabaceae are represented by values up to 7\%, and Ficus is locally significant at MP4 (18\%). 
Open woodland taxa reflect many of the trends already described. They are almost entirely composed of Myrtaceae (up to 70\%) and the canopy genera Eucalyptus and Melaleuca. Myrtaceae has background values in sites at some distance from a source, increasing in representation towards and across the forest-open woodland boundary (samples MP5 and MH3). Sample MH4 presents the only variation from this pattern, dominated by Pandanus (35\%) and significant in its representation of Banksia (10\%) and Leptocarpus (5\%). Dodonaea and other Sapindaceae are minor dryland components. Although Poaceae does travel into forest samples,

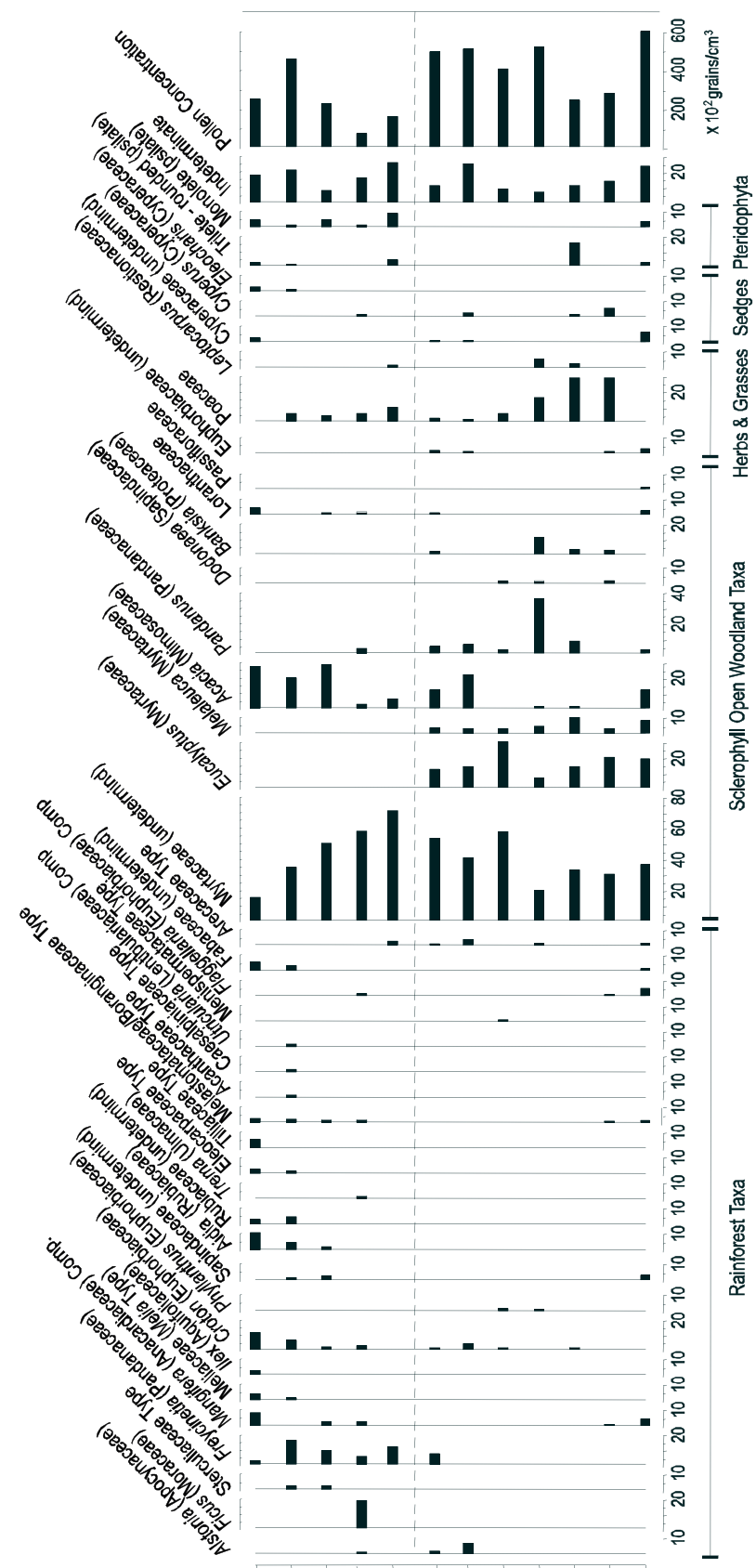

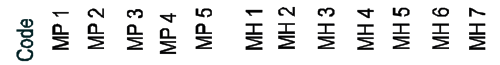

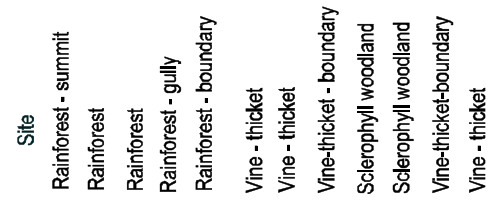

Figure 5. Rainforest pollen diagram. Modern pollen assemblages from Mulgrave Peak (upper diagram) and Mua Hillside (lower diagram) transects. Pollen are expressed as percentage values of the total pollen sum. 
it does not penetrate in great quantities $(<5 \%)$. Rather, Poaceae increases at the forest boundary (MH5) and makes a marked contribution to the open woodland samples of MH4-MH6 (up to $28 \%)$.

\section{Taxon representation}

The relative abundances of mangrove pollen types reflect the present zonation of plant species and provide a useful index of depositional environments and distance to the open coast. Identification of mangrove habitat by the dominance of Rhizophoraceae is a consistent observation across both Mua and Badu, and directly comparable to other regional mangrove palynological studies (e.g. Grindrod 1985; Crowley et al. 1994; Ellison 2005). High values of mangrove taxa (up to $95 \%$ of the total pollen sum) are recorded for lower-tidal mangrove sites, compared with the lower values of 30-60\% for upper-tidal and lowland coastal regions. Lowest mangrove pollen values are found at the landward extremity of intertidal mudflats. No mangrove pollen taxa are represented in terrestrial pollen samples associated with sclerophyll, inland Melaleuca-swamp, rainforest or vine-thicket communities, thus demonstrating a clear relationship between pollen source and mangrove distribution. Strong representation of Rhizophora pollen indicates frequently inundated saline environments. The representation of Rbizophora across the Waruid, Talita Kupai and Tiam Point transects reflects the nearmonospecific, local nature of the lower-tidal community. A lack of mangrove pollen diversity, with very low representation of grasses, sedges and herbaceous taxa, confirms the closed-canopy nature of this forest type.

Upper-tidal, landward mangrove vegetation is pollen distinguished from lower-tidal mangrove-forest on the basis of greater individual representation of taxa such as Ceriops and Bruguiera, Avicennia and Lumnitzera relative to Rhizophora (each of these taxa have restricted pollen dispersal, Grindrod 1985). In turn, the transition to saline mudflat or coastal backswamp surfaces incorporates increased terrestrial pollen components, reflecting reduced marine inundation and lower salinity of site samples. In agreement, Grindrod $(1985,1988)$ describes the strong representation of Avicennia pollen as particularly indicative of mainland Australian back-mangrove, brackish environments. On Mua and Badu, Ceriops and Bruguiera, Avicennia and Lumnitzera combine with Cyperaceae, Poaceae and herbaceous pollen such as Asteraceae and Freycinetia. The modern pollen data suggests that high values of Cyperaceae, as well as Chenopodiaceae, in fossil samples are locally derived, i.e. from a swamp surface or nearby. Crowley et al. (1994) confirm that values of Chenopodiaceae exceeding trace pollen levels indicate the presence of chenopods in local or extra-local vegetation, but warn also that absence cannot be assumed from lower values. High fern values, represented by monolete and trilete spores, are also indicative of coastal swamp surfaces, owing to the predominantly seasonal freshwater accumulation experienced at such sites. Acrostichum is the likely species recorded at Tiam Point, where the spores are trilete. Canopy vegetation in the mangrove/terrestrial transition and coastal swamp samples tends to be dominated by Melaleuca/Myrtaceae pollen derived from swamp Melaleuca species. A proportion of the Pandanus pollen rain also appears to be widely dispersed, but Pandanus dominates pollen assemblages where present in the vegetation (Crowley et al. 1994 also discuss Pandanus pollen deposition, both wetland and dryland).

The sclerophyll woodland sites are characterised by the pollen types of their dominant and sub-dominant tree species. Eucalyptus/Myrtaceae and Pandanus pollen indicate the principal canopy composition at the site. Other components such as Casuarina, Dodonaea, Acacia and Terminalia/Combretaceae and various herbs and lianes have poor, sporadic representation. Each is only likely to appear in a pollen sample when it is abundant in the vegetation of the area. Given the mosaic, open nature of the woodland/savanna vegetation, as well as its 
regional pollen distribution characteristics, it is probable that only large-scale canopy changes would be detected in the palaeoecological record. Grasses are consistently represented but, considering that they dominate the understorey of woodland and savanna areas, their pollen contribution is less than expected. Bush (2002) suggests the representation of tropical Poaceae pollen is influenced by numerous factors, including the pollination strategies of other members of their community and the scale of disturbance accompanying human activities. Bush (2002) cautions, in particular, against the interpretation of Poaceae pollen abundance without due regard to local hydrology. Using Poaceae as a simple indicator of regional vegetation change may overstate trends or boundary transitions towards aridity, and disregard seasonal variation in swamp communities. For environments such as Torres Strait, the persistence and timing of fire across woodland samples may also affect the Poaceae pollen record.

Inland swamp forest shows similar Poaceae pollen values to the sclerophyll surrounds, though they combine with high values and diversity within Cyperaceae and the presence of semi-aquatics such as Leptocarpus to indicate wetter conditions. Sites in which Leptocarpus and Cyperaceae are prominent in the vegetation are clearly identified by the domination by these taxa of the pollen spectra. Deduction of water depth and permanency on the basis of the pollen assemblage is, however, more difficult. The majority of samples comes from sites of fluctuating water levels. It could be concluded that Cyperaceae and Leptocarpus pollen are better indicators of shallow (or seasonal) surface water than Melaleuca. Higher pollen values of dryland taxa with low pollen production or poor dispersal may also signify shallow water or a high water table. Here, the associated moisture and organic sediment type would allow for greater preservation and entrapment of such pollen. Melaleuca pollen associated with a greater regional component is therefore more likely to reflect prominent areas of open water. The improved identification of Melaleuca will be important for the refined recognition of free water, particularly so in the observed absence of pollen from Nymphoides and the like. Overall, the inland surface study gives confidence that local swamp pollen can be separated from regional pollen sources.

There is a comparatively high level of diversity among the monsoonal-rainforest and vinethicket pollen samples. No one pollen type dominates; numerous taxa were found to contribute to the pollen signature and, although widely separated, the two rainforest transect studies show similar pollen spectra. On Mua and Badu, rainforest pollen behaviour resembles analyses from mainland humid tropical locations (Kershaw and Strickland 1990; Kershaw and Bulman 1994; Walker and Sun 2000). Linking trends include pollen diversity, but also a penetration of nonrainforest tree pollen to a point exceeding rainforest pollen itself. Similarly, many taxa will not be represented in pollen diagrams given that, within closed forest zones, long-distance pollen dispersal is of little importance; taxa are typically recorded only if growing in proximity to the pollen collection site (i.e. dominant local deposition). However, the two locations vary in their pollen rain composition. Major canopy or emergent tree taxa (e.g. Stenocarpus, Acmena) are high pollen contributors to the mainland humid tropical records, as are palms and ferns (tree, epiphytic and/or ground ferns). A lack of distinction within the Myrtaceae and Acacia pollen at both Mulgrave Peak and Mua Hillside has hampered the isolation of rainforest vegetation, and the monsoonal communities are differentiated by the presence of Ficus, Aidia, Croton and Freycinetia pollen. Although each taxon appeared in extremely low quantities, these low pollen values do not necessarily mean insignificant results. The simple presence/absence of pollen taxa is considered important in differentiating monsoonal rainforest vegetation, and in representing forest patchiness, and may provide a data set more likely to be comparable with a fossil record than percentile data. Burn et al. (2010) make a similar observation in the pollen differentiation of Amazonian rainforest communities. Plants may be well represented in floristic inventories, but under-represented in the pollen because their pollen is less well dispersed. Where such pollen is found within the pollen rain, its presence can provide significant ecological information with 


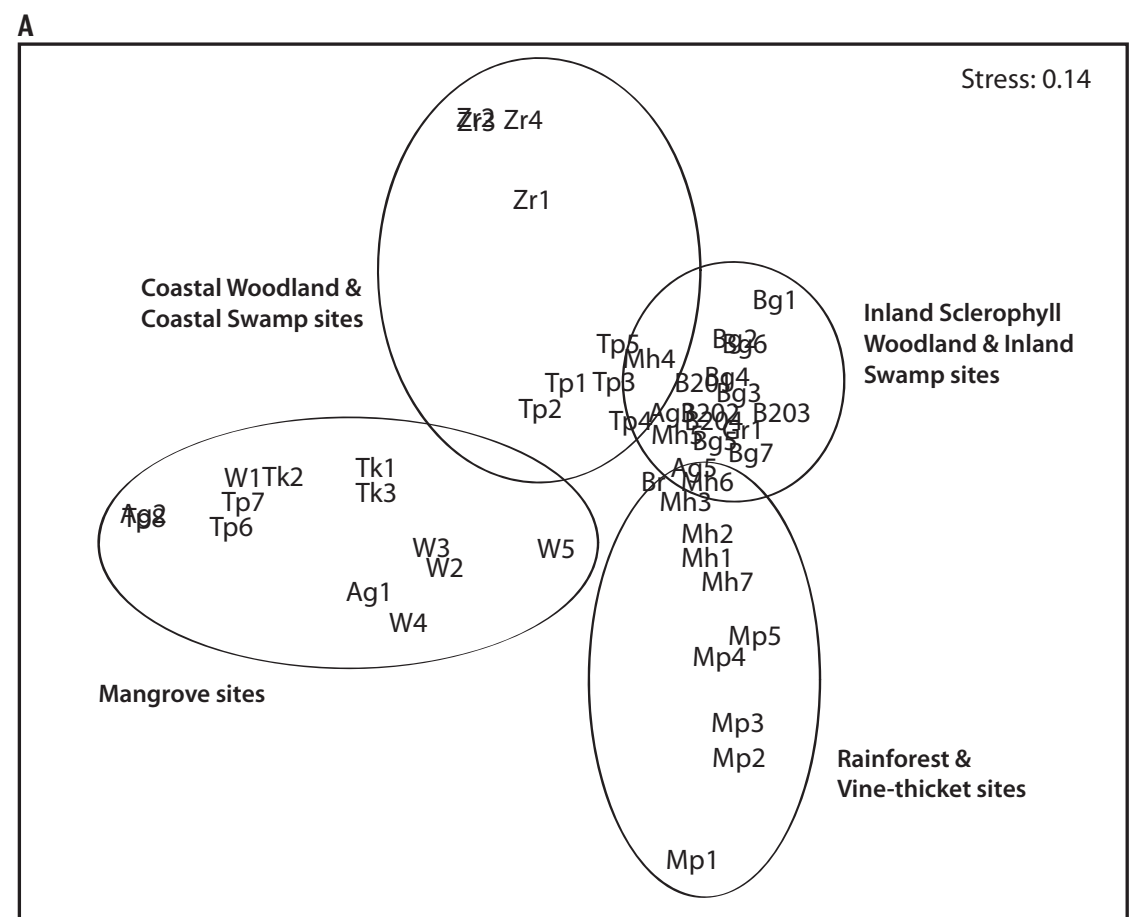

B

\begin{tabular}{|c|c|c|c|}
\hline \multicolumn{2}{|c|}{ Group: Mangrove } & \multicolumn{2}{|c|}{ Group: Coastal Woodland } \\
\hline Taxa & \%Contrib & Taxa & \%Contrib \\
\hline Rhizophora & $50.53^{*}$ & Poaceae & $22.51^{*}$ \\
\hline Myrtaceae & 12.80 & Pandanus & $21.47^{*}$ \\
\hline Avicennia & 7.19* & Myrtaceae & 19.11 \\
\hline Eucalyptus & 4.96 & Eucalyptus & 9.70 \\
\hline Bruguiera & 4.85 & Melaleuca & 8.40 \\
\hline Lumnitzera & 4.79 & Cyperus & 7.38 \\
\hline Ceriops & 4.06 & Rhizophora & 4.18 \\
\hline Poaceae & 3.43 & & \\
\hline \multicolumn{2}{|c|}{ Group: Coastal Swamp } & \multicolumn{2}{|c|}{ Group: Inland Swamp } \\
\hline Taxa & \%Contrib & Taxa & \%Contrib \\
\hline Pandanus & $43.47^{*}$ & Melaleuca & $27.04^{*}$ \\
\hline Poaceae & $11.82^{*}$ & Eucalyptus & 19.94 \\
\hline Rhizophora & 11.33 & Myrtaceae & 17.49 \\
\hline Cyperus & 8.80 & Leptocarpus & $14.40^{*}$ \\
\hline Myrtaceae & 8.40 & Poaceae & 8.19 \\
\hline Bruguiera & 4.76 & Cyperus & 6.37 \\
\hline Melaleuca & 3.22 & & \\
\hline \multicolumn{2}{|c|}{ Group: Sclerophyll Woodland } & \multicolumn{2}{|l|}{ Group: Rainforest } \\
\hline Taxa & \%Contrib & Taxa & \%Contrib \\
\hline Myrtaceae & $33.90 *$ & Myrtaceae & 37.42 \\
\hline Eucalyptus & $20.25 *$ & Acacia & $17.49 *$ \\
\hline Poaceae & 16.73 & Freycinetia & $15.21 *$ \\
\hline Melaleuca & 21.71 & Poaceae & 8.98 \\
\hline Banksia & 4.46 & Croton & $5.76^{*}$ \\
\hline \multirow[t]{2}{*}{ Pandanus } & 4.13 & Melastomataceae & 3.90 \\
\hline & & Mangifera & 2.66 \\
\hline \multicolumn{2}{|c|}{ Group: Vine-thicket } & & \\
\hline Taxa & \%Contrib & & \\
\hline Myrtaceae & 36.09 & & \\
\hline
\end{tabular}

Eucalyptus $\quad 20.96$

Pandanus $\quad 9.32$

Melaleuca $\quad 9.20$

\begin{tabular}{l|l} 
Acacia & 9.04
\end{tabular}

\begin{tabular}{l|l} 
Poaceae & 3.74
\end{tabular}

\begin{tabular}{l|l} 
Croton & $2.65^{*}$ \\
\hline
\end{tabular}

Figure 6. A. Multi-dimensional ordination (MDS) using group-average linking on Bray-Curtis sediment sample similarities (50 modern pollen samples). B. ANOSIM percentages highlighting taxon contribution (\%Contrib) influencing observed similarity cluster through the ordination in Figure 6a. 
regards to local vegetation and aid palynological characterisation (Burn et al. 2010). Drier rainforest formations, therefore, are best separated on the basis of the pollen assemblage, rather than any one taxon.

\section{Multivariate analysis of modern pollen}

The pollen samples have been highlighted according to their respective environmental zone (mangrove, coastal lowland, inland swamp and sclerophyll, and rainforest). The ordination (MDS plot Figure 6a) highlights the relationships between vegetation groups while still acknowledging a degree of within-group variability. It is encouraging that no scores are scattered throughout the ordination. Rather, the tight grouping observed within and around inland swamp and sclerophyll samples is identified as the predominant feature. In essence, these open-canopy vegetation sites show a greater similarity within group than is evident in the mangrove and rainforest groups. A similar, although lesser, trend through the coastal lowland samples is also apparent. Here, the increased importance of regional pollen rain (and its uniformity) in open vegetation sites is a significant factor in reducing variability. The mangrove forest system and rainforest group are clearly distinguishable, and the Zurath samples form a cluster separate from all other samples. This pattern is driven largely by the presence of Pandanus and absence of Myrtaceae at Zurath. Coastal swampland is appreciably different from both mangrove and coastal woodland habitats, though closer in approximation to the latter. Vine thicket separates from monsoonal rainforest, approaching sclerophyll woodland in its similarity. The positioning of vine-thicket samples is indicative of the more open nature of its canopy, allowing for a greater regional signal and shared flora, particularly in the presence of sclerophyll emergents.

When considering Figure 6a, strength of the ordination lies in displaying a gradation in vegetation formation across the set of samples. A changing pollen assemblage can be traced from the mangrove forest through the wider coastal environment (firstly incorporating coastal swampland, then coastal woodland), to the more coherent sclerophyll interior. Likewise, a separation of the rainforest samples extends stepwise from the inland swamp to sclerophyll woodlands, blending with vine thicket and stretching through the rainforest at high elevations.

\section{Determining discriminating taxa}

The contribution each pollen taxon makes to the observed ordination and/or average sample similarity within the vegetation groups of Figure 6a is shown in Figure 6b. Figure 6b reveals species which are statistically typical of a group; pollen taxa are ordered by their average contribution (\%Contrib) and those considered good discriminators in this study are indicated by an asterisk.

In many cases, close to half the average similarity value is accounted for by only two pollen taxa, with $90 \%$ of a group's distinction represented by no more than seven taxa. Undoubtedly, the mangrove pollen group is distinguished through Rhizophora, independently accounting for $51 \%$ of average within-group similarity. Avicennia is also significant, at $7 \%$. Poaceae and Pandanus contribute equally to the coastal woodland group, at 22\%; Pandanus is a better representative of the coastal swamp: 44\%. The Myrtaceae family maintains a significant presence within the sclerophyll woodland, inland swamp, vine-thicket and rainforest groups. While Melaleuca is particular to the inland swamp, contributing 34\%, the remaining groups are perhaps best described through other non-Myrtaceae taxa specific to their list. In this respect, sclerophyll woodland is defined via Poaceae as well as Eucalyptus pollen, and rainforest through Acacia, Freycinetia and Croton. A lack of distinction within the Myrtaceae family remains a problem when identifying vine-thicket communities. Croton is therefore the only pollen taxon highlighted. 
Table 3. Guiding principles for the interpretation of fossil pollen assemblages, as specified from modern pollen samples in Torres Strait.

\begin{tabular}{|c|c|c|}
\hline Pollen sum observation & Pollen dispersal & Interpretation \\
\hline Rhizophora >50\% & Regional & Lower-tidal, inundated mangrove \\
\hline Rhizophora <50\% & Regional & $\begin{array}{l}\text { Upper-tidal mangrove \& adjacent } \\
\text { mangrove-terrestrial transition }\end{array}$ \\
\hline Avicennia >10\% & Local & Upper-tidal mangrove \\
\hline $\begin{array}{l}\text { Present - Ceriops, Bruguiera, } \\
\text { Lumnitzera, Avicennia, Xylocarpus, } \\
\text { Excoecaria }\end{array}$ & Local/Extra-local & $\begin{array}{l}\text { Upper-tidal mangrove and adjacent } \\
\text { mangrove-terrestrial transition }\end{array}$ \\
\hline Chenopodiaceae > trace level & Local & Mudflat, saltmarsh \\
\hline Spore types (cumulative) >20\% & Local & Swamp surface \\
\hline Spore types (cumulative) <10\% & Local & Myrtaceous open forest to woodland \\
\hline Pandanus $>20 \%$ & Local & Localised stand; swamp nearby \\
\hline Present - Pandanus, Melaleuca & Extra-local/Regional & Swamp surface and/or swamp nearby \\
\hline $\begin{array}{l}\text { High Cyperaceae; Present - Cyperus, } \\
\text { Eleocharis, Schoenus, Poaceae }\end{array}$ & Local/Extra-local & $\begin{array}{l}\text { Swamp surface; inundated sediments/ } \\
\text { depression }\end{array}$ \\
\hline Present - Сурегасеае, Leptocarpus & Local/Extra-local & $\begin{array}{l}\text { Moist sediment surface, localised poor } \\
\text { drainage }\end{array}$ \\
\hline Leptocarpus >20\% & Local/Extra-local & Wet swamp surface \\
\hline Poaceae $>10 \%$ & Extra-local/Regional & Grasses abundant in local vegetation \\
\hline Melaleuca >20\% & Extra-local/Regional & $\begin{array}{l}\text { Wet swamp surface nearby; open } \\
\text { water }\end{array}$ \\
\hline Eucalyptus >20\% & Regional & Open forest; woodland \\
\hline Myrtaceae $>25 \%$ & Regional & 0pen forest; woodland \\
\hline Ficus >trace level & Local & $\begin{array}{l}\text { Monsoonal rainforest (established } \\
\text { closed forest) }\end{array}$ \\
\hline Present - Freycinetia, Aidia, Mangnifera & Local & Monsoonal rainforest \\
\hline Acacia $>20 \%$ & Extra-local/Regional & Monsoonal rainforest \\
\hline Freycinetia >10\% & Local & $\begin{array}{l}\text { Monsoonal rainforest - Sclerophyll } \\
\text { transition }\end{array}$ \\
\hline $\begin{array}{l}\text { Present - Myrtaceae, Terminalia, Ilex, } \\
\text { Hibiscus, Acacia, Alstonia }\end{array}$ & Local/Extra-local & Mixed canopy forest in region \\
\hline
\end{tabular}

A total of 11 pollen taxa have been identified as principally responsible for the observed clustering in Figures 6a and 6b. Between them, Rbizophora, Avicennia, Pandanus, Poaceae, Myrtaceae, Eucalyptus, Melaleuca, Leptocarpus, Acacia, Freycinetia and Croton capture the full multivariate pattern. However, identifying taxa as typical of a vegetation group does not necessarily correspond to an equal importance in discriminating from one group to another. Taxa may be typical of a number of groups, and the example of Myrtaceae has affected the degree to which environments across island interiors can be statistically separated.

\section{Concluding discussion}

As a first study of its kind for Torres Strait, the modern pollen spectra have allowed for the establishment of guidelines for the interpretation of fossil pollen diagrams (Table 3). This research has shown the importance of independently describing the modern pollen rain from monsoonal Cape York Peninsula, and testing pollen's diagnostic qualities in capturing vegetation heterogeneity. The approach incorporated a visual interpretation of broad trends in the pollen data with statistical analyses of these trends and their significance. The analyses of similarity support each percentage pollen diagram in describing the pollen assemblages and in isolating useful indicators of vegetation and ecological settings. Together, the results show that the modern pollen rain does vary and vegetation groups (structurally and in composition) can be differentiated. 
The pollen from a wide range of vegetation associations contained within the mangrove, coastal, inland swamp and sclerophyll, and rainforest environmental zones can be explained in terms of local, extra-local and regional components. The majority of taxa recorded were local or extra-local. Locally produced and dispersed pollen types are highly variable between samples and sites, while regional pollen types have relatively even fallout. Key examples of local taxa include Avicennia, Leptocarpus, Freycinetia and Croton. Regional dispersal, while contributing considerably to the pollen sum, particularly in open environments, is restricted to a few canopy taxa such as Eucalyptus and Myrtaceae, and notably Rhizophora across coastal landscapes. Based on the pollen diagrams, Pandanus behaves in a similar regional manner, but one important result that follows on from the ordination is that palynological dominance of Pandanus is indicative of local swamp conditions, especially within coastal lowlands. From the pollen diagrams, Cyperaceae is a minor component of terrestrial communities, but is also diagnostic of swamp communities in high percentages and diverse genus types. When palaeoecological discussions combine with archaeological interpretations, as has occurred in the Torres Strait (Crouch et al. 2007), such swamp (i.e. freshwater availability) indicators are noteworthy. This modern pollen study also suggests that the overall assemblage, as opposed to exclusive reliance on individual pollen types and irrespective of grain percentages, is a useful indicator - valuable in the documentation of monsoonal rainforest as well as upper-tidal mangrove environments, for example. Diverse pollen assemblages have been comprehensively used in the documentation of Torres Strait Holocene coastal changes (Rowe 2007b), but require stronger use inland to be considered outside of Myrtaceae pollen trends. An important lesson for the interpretation of Torres Strait palaeovegetation (e.g. Rowe 2008) further rests within the described gradation of samples across Figure 6a. Boundaries between vegetation communities will not always be sharp, introducing the concept of extensive ecotones as important components of the landscape and indicators of spatial vegetation shift. Once again, the smaller understorey and/or secondary plant growth indicators - the so-called micro-trends - exist as valuable explanatory components.

While the guidelines in Table 3 can assist in the interpretation of fossil pollen assemblages, the study has also highlighted certain difficulties in obtaining precise signatures. Upon inspection of the pollen diagrams, there is considerable similarity between the overall pollen assemblage of coastal woodland, inland sclerophyll woodland and vine-thicket communities, exemplified by the tight clustering observed in the ordination. High levels of Myrtaceae pollen are one reason it is difficult to separate these three different vegetation types. It should also be considered that regular burning activities may serve to create more uniform vegetation and corresponding pollen assemblages across dryland environments, fire blurring the distinction between sediment samples collected within different vegetation communities. In future analyses, modern pollen and charcoal counts should be used together to determine the level of fire disturbance evident in any given sample. Further research also needs to examine modern pollen representation across environmental gradients. Altitude, soil moisture, nutrient status and salinity could be incorporated, in addition to charcoal. Such measurement would improve an understanding of sample ordination, for example, and assist in documenting wider spatial and temporal connections between vegetation groups.

The fact that fewer than half the surface samples collected were used in this study highlights some limitations in litter collections across seasonal environments (sandy and thin, dry sediments). The sedimentary surface is an active, oxidative environment and pollen was found in varied degradative states in all sediment types and locations. This contrasts with wet sedimentary environments, where sediments become anoxic and abiotic as they are buried and where pollen recovery tends towards relatively fresh preservation. At the surface, differential preservation and degradation, and differential recognition of poorly preserved grains might have resulted in some bias, robust grains assuming a more important interpretative role than 
might otherwise occur in damp sedimentary fossil collections (Hall 1981; Orvis 1998). As such, there is also a need to adopt additional sampling strategies, such as pollen traps, if this work is to be extended.

In conclusion, the usefulness of modern pollen data from Torres Strait is not limited to this region alone. Demonstrated characterisation of island monsoonal, megatherm vegetation pollen signatures can be usefully applied to a refined understanding of seasonal tropical mainland Australia, a region in which few investigations of modern and fossil pollen rain have been made.

\section{Acknowledgements}

This research was supported by Monash University's School of Geography and Environmental Science, with special thanks to the Western Torres Strait Cultural Heritage Project team for their assistance and encouragement. Warm thanks to the people of Mua and Badu for permission to undertake island palaeoecological research, and for their hospitality during fieldwork. The author also acknowledges the Mura Badulgal Corporation which kindly provided ongoing permission to publish. Thanks are also extended to the editors of this volume and to the anonymous referees for feedback and comment.

\section{References}

Abrahams, H., Mulvaney, M., Glasco, D. and Bugg, A. 1995. An assessment of the Conservation and Natural Heritage Significance of Cape York Peninsula. Cape York Peninsula Land Use Study. Queensland Environment Protection Agency - Brisbane, Australian Government Department of Environment and Heritage, Canberra, ACT.

Bain, J.H.C. and Draper, J.J. 1997. North Queensland Geology. AGSO Bulletin 240/Queensland Geology 9, Queensland Department of Mines and Energy.

Beasley, J. 2009. Plants of Cape York. Everbest Publishing, Queensland.

Brock, J. 2001. Native plants of northern Australia. Reed New Holland, Sydney.

Burn, M.J. Mayle, F. and Kileen, T.J. 2010. Pollen-based differentiation of Amazonian rainforest communities and implications for lowland palaeoecology in tropical South America. Palaeogeography, Palaeoclimatology, Palaeoecology 295:1-18.

Bush, M.B. 2002. On the interpretation of fossil Poaceae pollen in the lowland humid neotropics. Palaeogeography, Palaeoclimatology, Palaeoecology 177:5-17.

Chalson, J.M. 1989. The late Quaternary vegetation and climatic history of the Blue Mountains, New South Wales, Australia. Unpublished PhD thesis, University of NSW.

Clarke, K.R. 1993. Non-parametric multivariate analysis of changes in community structure. Australian Journal of Ecology 18:117-143.

Clarke, K.R. and Gorley, R.N. 2001. PRIMER v5: User Manual/Tutorial. PRIMER-E Ltd, Plymouth Marine Laboratory, Plymouth.

Clarke, K.R. and Warwick, R.M. 2001. Change in marine communities: an approach to statistical analysis and interpretation. 2nd edition. PRIMER-E Ltd. Plymouth Marine Laboratory, Plymouth.

Crouch, J., McNiven, I., David, B., Rowe, C. and Weisler, M. 2007. Berberass: marine resource specialisation and environmental change in Torres Strait during the last 4000 years. Archaeology in Oceania 42:49-62.

Crowley, G.M., Grindrod, J. and Kershaw, A.P.K. 1994. Modern pollen deposition in the tropical lowlands of northeaster Queensland, Australia. Review of Palaeobotany and Palynology 83:299-327. 
Denham, T. and Mooney, S. 2008. Human-environment interactions in Australia and New Guinea during the Holocene. The Holocene 18:365-371.

Department of Environment and Heritage 2007. Australia's Native Vegetation: Australian Major Vegetation Groups, 2007. Australian Government, Canberra, ACT.

Ellison, J. 2005. Holocene palynology and sea-level change in two estuaries in Southern Irian Jaya. Palaeogeography, Palaeoclimatology, Palaeoecology 3-4:291-309.

Faegri, K. and Iversen, J. 1989. Textbook of Pollen Analysis (4th edition). Wiley, Chichester.

Faith D.P., Minchin P.R. and Belbin, L. 1987. Compositional dissimilarity as a robust measure of ecological distance. Vegetatio 69:57-68.

Fox, I.D., Neldner, V.J., Wilson, G.W. and Barrick, P.J. 2001. The Vegetation of Australian Tropical Savannas. Environmental Protection Agency, Brisbane, Queensland.

Froyd,C.A. and Willis, K.J.2008. Emerging issues in biodiversity and conservation management: the need for a palaeoecological perspective. Quaternary Science Reviews 27:1723-1732.

Fuhsiung, W., Nanfen, C., Yolong, Z. and Huiqiu, Y. 1997. Pollen flora of China (2nd edition). Institute of Botany, Academia Sinica.

Grindrod, J. 1985. The palynology of mangroves on a prograded shore, Princess Charlotte Bay, north Queensland, Australia. Journal of Biogeography 12:323-348.

Grindrod, J. 1988. Holocene mangrove history of the South Alligator River estuary, Northern Territory, Australia. Unpublished PhD Thesis, Australian National University, Canberra.

Grindrod,J. and Rhodes, E.G. 1984. Holocene sea level history of a tropical estuary: Missionary Bay, north Queensland. In: Thom, B.G. (ed), Coastal Geomorphology in Australia. Academic Press, London, pp. 151-178.

Grimm, E. 1988. Data Analysis and Display. In: Huntley, B. and Webb, T. (eds), Handbook of Vegetation Science, Volume 7. Kluwer Academic Publisher, Dordrecht, pp. 43-76.

Haberle, S.G. 2005. A 23,000-yr pollen record from Lake Euramoo, Wet Tropics of NE Queensland, Australia. Quaternary Research 64:343-356.

Hall, S.A. 1981. Deteriorated pollen grains and the interpretation of Quaternary pollen diagrams. Review of Palaeobotany and Palynology 32:193-206.

Harrison, S.P., Zhao, Y., Rowe, C. and Marshall, A. 2007. Climates, fire regimes and vegetation patterns of Australia during the past 70,000 years: observations and model results. Quaternary International 167:156-157.

Kershaw, A.P. 1971. A pollen diagram from Quincan Crater, north-east Queensland, Australia. New Phytologist 70:669-681.

Kershaw, A.P. 1985. An extended late Quaternary vegetation record from north-eastern Queensland and its implications for the seasonal tropics of Australia. Proceedings of the Ecological Society of Australia 13:179-189.

Kershaw, A.P. 1992. The development of rainforest-savanna boundaries in tropical Australia. In: Furley, P.A., Proctor, J. and Ratter, J.A. (eds), Nature and dynamics of forest-savanna boundaries. Chapman and Hall, London, pp. 255-271.

Kershaw, A.P. 1995. Environmental change in Greater Australia. Antiquity 69:656-675.

Kershaw, A.P. and Strickland, K.M. 1990. A 10 year pollen trapping record from rainforest in northeastern Queensland, Australia. Review of Palaeobotany and Palynology 64:281-288.

Kershaw, A.P. and Bulman, D. 1994. The relationship between modern pollen samples and environment in the humid tropical region of northeastern Australia. Review of Palaeobotany and Palynology 83:83-96.

Kershaw, A.P., Moss, P. and van der Kaars, S. 1997. Environmental change and the human occupation of Australia. Anthropologie 35:35-43.

Kershaw, A.P. 2007. Preface: Environmental History of the Humid Tropics region of northeast Australia. Palaeogeography, Palaeoclimatology, Palaeoecology 251:1-3. 
Kershaw, A.P., Bretherton, S. and van der Kaars, S. 2007. A complete pollen record of the last 230 ka from Lynch's Crater, north-eastern Australia. Palaeogeography, Palaeoclimatology, Palaeoecology 251:23-45.

Lynch, A.H., Beringer, J., Kershaw, A.P., Marshall, A., Mooney, S., Tapper, N., Turney, C. and van der Kaars, S. 2007. Using the Palaeorecord to Evaluate Climate and Fire Interactions in Australia. Annual Review of Earth and Planetary Sciences 35:215-239.

Mackey, B.G., Nix, H.A. and Hitchcock, P. 2001. The natural heritage significance of Cape York Peninsula. ANUTECH Pty. Ltd. and Queensland Environmental Protection Agency, Brisbane.

McNiven, I., David, B. and Barker, B. 2007. The social archaeology of Indigenous Australia. In: David, B., Barker, B. and McNiven, I. (eds), The Social Archaeology of Australian Indigenous Societies. Aboriginal Studies Press, Canberra, Australia, pp. 2-20.

Neldner, V.J. and Clarkson, J.R. 1995. Vegetation Survey and Mapping of Cape York Peninsula. Cape York Peninsula Land Use Study, Queensland Environment Protection Agency Brisbane, Australian Government - Department of Environment and Heritage, Canberra, ACT.

Orvis, K.H. 1998. Modern surface pollen from three transects across the southern Sonoran Desert margin, Northwestern Mexico. Palynology 22:197-211.

Pickett, E.J., Harrison, S.P., Hope, G., Harle, K., Dodson, J., Kershaw, A.P., Prentice, I.C., Haberle, S., Hassell, C., Kenyon, C., Macphail, M., Martin, H., Martin, A.H., McKenzie, M., Newsome, J.C., Penny, D., Powell, J., Raine, J.I., Southern, W., Stevenson, J., Sutra, J.P., Thomas, I., van der Kaars, S. and Ward, J. 2004. Pollen based reconstructions of biome distributions for Australia, Southeast Asia and the Pacific (SEAPAC) region at 0,6000 and 18,000 14C yr BP. Journal of Biogeography 31:1381-1444.

Overpeck, J.T., Webb, T. and Prentice, I.C. 1985. Quantitative interpretation of fossil pollen spectra: dissimilarity coefficients and the method of modern analogues. Quaternary Research 23:87-108.

Rowe, C. 2007a. A palynological investigation of Holocene vegetation change in Torres Strait, seasonal tropics of northern Australia. Palaeogeography, Palaeoclimatology and Palaeoecology. 25:83-103.

Rowe, C. 2007b. Vegetation change following mid-Holocene marine transgression of the Torres Strait shelf: a record from Mua. The Holocene 17:917-927.

Rowe, C. 2008. Holocene vegetation change on Mua. In: David, B., Tomsana, D. and Quinnell, M. (eds), Gelam's Homeland: cultural history on the island of Mua, Torres Strait. Memoirs of the Queensland Museum: Cultural Heritage Series 4:593-604.

Stern, H., de Hoedt, G. and Ernst, J. 2000. Objective classification of Australian climates. Australian Meteorological Magazine 49:87-96.

Tauber, H. 1967. Investigations of the mode of pollen transfer in forested areas. Review of Palaeobotany and Palynology 3:277-286.

Thanikaimoni, G. 1987. Mangrove Palynology UNDP/UNESCO Regional Project on training and research on mangrove ecosystems. RAS/79/002, French Institute.

Turner, H., Hovenkamp, P. and van Welzen, P.C. 2001. Biogeography and Southeast Asia and the West Pacific. Journal of Biogeography 28:217-230.

Torres Strait Regional Authority 2007. The Torres Strait: Torres Strait Annual Report 20062007. http://www.tsra.gov.au

Walker, J. and Hopkins, M.S. 1990. Vegetation. In: McDonald, R.C., Isbell, R.F., Speight, J.G., Walker, J. and Hopkins, M.S. (eds), Australian Soil and Land Survey. Field Handbook (2nd edition). Australian Collaborative Land Evaluation Program, CSIRO, Canberra. pp. 58-86. 
Walker, D. and Sun, X. 2000. Pollen fall-out from a tropical vegetation mosaic. Review of Palaeobotany and Palynology 110:229-246.

Wannam, B. 2008. Terrestrial Vegetation of Gelam's homeland, Mua. Memoirs of the Queensland Museum (Cultural Heritage Series) 4:605-615. 